\title{
Refugees, Rights, and Race: How Legal Status Shapes Liberian Immigrants' Relationship with the State
}

\author{
Dr. Hana E. Brown \\ brownhe@wfu.edu
}

\begin{abstract}
$\underline{\text { Abstract }}$
Drawing on three years of participant-observation in a Liberian immigrant community, this article examines the role of legal refugee status in immigrants' daily encounters with the state. Using the literature on immigrant incorporation, claims-making, and citizenship, it argues that refugee status profoundly shapes individuals' views and expectations of their host government as well as their interactions with the medical, educational, and social service institutions they encounter. The refugees in this study use their refugee status to make claims for legal and social citizenship and to distance themselves from native-born Blacks. In doing so, they validate their own position vis-àvis the state and in the American ethno-racial hierarchy. The findings presented demonstrate how refugee status operates as a symbolic and interpretive resource used to negotiate the structural realities of the welfare state and American race relations. These results stress the importance of studying immigrant incorporation from a micro perspective and suggest mechanisms for the adaptational advantages for refugees reported in existing research.
\end{abstract}

Keywords: race, immigration, Africa, incorporation, refugee

Acknowledgements: For their helpful comments on earlier version of this article the author thanks Irene Bloemraad, Dawne Moon, Sandra Smith, Rachel Best, Jennifer Carlson, Kimberly Hoang, Daniel Laurison, Laura Mangels, Sarah Anne Minkin, and participants in the Berkeley Interdisciplinary Immigration Workshop and Berkeley Sociology Race Workshop. 


\section{Refugees, Rights, and Race: How Legal Status Shapes Liberian Immigrants' Relationship to the State}

The rapid rise in immigration to the United States over the last decades has generated significant scholarly interest in the issue of incorporation, the process by which immigrants adapt to and gain membership in a receiving society. Central to these conversations is the importance of immigrants' legal status for their integration (Massey, Durand, and Malone 2002; Menjivar 2006; Portes and Rumbaut 2006). These legal categories and the programs and stipulations that accompany them have major implications for immigrants and host societies alike. Legal status determines not only how long an individual can remain in the United States but also under what conditions, doing what work, and receiving which social and economic supports. Although researchers have traditionally examined legal status as it relates to assimilation (Gans 1992; Portes and Zhou 1996), labor market outcomes (Phillips and Massey 1999), and transnationalism (Massey, Goldring, and Durand 1994, Ong 2000), an emerging literature examines how documentation status (or lack thereof) shapes immigrants' relationships to their host state, particularly the meaning they give to their own citizenship and social membership (Coll 2004, Menjivar 2006). In this study, I expand on these literatures by examining the incorporation of legal refugees. Unlike earlier studies which examine the macro-level incorporation of refugees (Portes and Rumbaut 2006; Waxman 2001), this paper analyzes their micro-level incorporation and interrogates refugees' definitions of citizenship and social membership.

According to the 1951 United Nations' Convention Relating to the Status of Refugees, a refugee is someone who, "owing to a well-founded fear of being persecuted for reasons of race, religion, nationality, membership in a particular social group, or 
political opinion, is outside the country of his nationality, and is unable to or, owing to such fear, is unwilling to avail himself of the protection of that country." While in popular discourse the term refers to anyone forced to leave their home due to persecution, war, or even natural disaster, individuals who hold legal refugee status are admitted to the United States under a unique combination of policies and programs. Legal refugees are the most protected group of immigrants in the United States. They apply for legal refugee status from abroad, often after years of living in remote and poorly-equipped refugee camps. If accepted, the United States government arranges their plane transportation to the U.S. Upon arrival, they have pre-arranged housing, immediate access to an array of social programs denied to other immigrants, and a minimum of three months of job, language, and other assistance from federally-funded resettlement agencies.

The unique refugee migration trajectory begs two interrelated questions with implications for our broader understanding of the immigrant incorporation process. Is refugee status a salient factor in the day-to-day life experiences of those who hold it? Do the state-guided refugee migration experience and the official refugee designation shape legal refugees' relationship to their host state and society? To address these questions, I draw on three years of participant-observation in a West African refugee community in California. I present data on these refugees' interactions with medical, educational, and social service institutions, highlighting the claims for rights that they make on state agencies. I focus on everyday claims-making because it is in these regular encounters with the state that individuals formalize and express their understanding of their membership in and their expectations of their new country. 
Drawing on this evidence, I argue that, in this community, refugees' claimsmaking strategies reveal a fundamentally different notion of the citizen-state relationship than currently appears in the research. Unlike legal immigrants who make claims to the state based on their work participation (Kurthen 1997; Nakano-Glenn 2004) or undocumented and temporary immigrants who are ambivalent or fearful of the state (Bannerjee 2006; Menjivar 2006), the refugees in this study cite their legal refugee status and federal refugee programs as evidence of a strong and personal relationship with the United States government. They use their refugee status to make claims for legal and social citizenship and to distinguish themselves from African-Americans who share their phenotype but not their refugee status. In doing so, they attempt to establish their own position vis-à-vis the U.S. state and in American ethno-racial hierarchy.

This study has multiple implications for our understanding of the immigrant adaptation process. First, it highlights the importance of moving beyond the dichotomy between documented and undocumented immigrants to assess the impact of specific legal statuses on immigrant incorporation. That refugee status guides the claims-making and racial distancing efforts of these refugees suggests that state immigration statuses alter the relationship that immigrants have with the government and how they view themselves in the larger matrix of American society. Second, these findings underscore the importance of analyzing immigrant incorporation from a micro perspective. A micro-level analysis redirects our attention from economic incorporation to refugee status as a symbolic and interpretive resource used to negotiate the structural realities of the welfare state and American race relations. Furthermore, by showing how refugees successfully use their status to make claims for legal and social membership, this study offers a potential 
explanation for the economic and political adaptational advantages refugees have over other immigrants (Bloemraad 2006; Portes and Rumbaut 2006; Portes and Zhou 1993). As a result, the study suggests that reception policies may be tailored to encourage the incorporation of new immigrants.

\section{$\underline{\text { Legal Status, Incorporation, and Refugee-State Relations }}$}

Historically, the immigration literature has found its nexus in debates about assimilation and transnationalism, emphasizing the incorporation of immigrants into the labor market or enclave economies (Gans 1992; Massey, Goldring, and Durand 1994; Portes 2006; Smith 1994). This focus on economic adaptation is warranted given the labor market's central place in U.S. immigrant incorporation. Unlike in other western democracies where the state and ethno-national organizations play an active role in immigrant incorporation, incorporation in liberal states like the U.S. is accomplished primarily through the labor market (Kurthen 1997; Soysal 1995). Paralleling studies of immigrant economic outcomes is a growing literature on immigrants' understanding of their citizenship and social membership. These studies reaffirm the centrality of the labor market for immigrants, finding that in making claims on the state, documented immigrants portray themselves as ideal citizen-workers: hard working, independent, and responsible taxpayers (Guevarra 2010; Kurthen 1997; Reese and Ramirez 2002). In doing so, they rely on their labor market participation and their control over their own labor power to further their own claims for rights and social membership while delegitimizing others (Nakano-Glenn 2004; Roediger 1991). 
Like documented immigrants, undocumented immigrants in the United States are typically incorporated through the labor market; however, their lack of legal status affects their life chances, their economic outcomes, their health, and their social integration (Massey, Durand, and Malone 2002; Menjivar 2006). Undocumented immigrants face wage discrimination (Philips and Massey 1999) and are unlikely to seek legal redress when their rights are violated (Salcido and Adelman 2004). Public health workers discourage undocumented Mexican immigrants from seeking care and making claims for assistance, leading to poor health outcomes in the population (Horton 2004). A lack of legal immigration status combined with the constant threat of workplace raids and deportation give undocumented immigrants an uncertain and sometimes fearful view of the state and host society (Coll 2004). Immigrants with temporary legal status experience similar ambivalence and marginalization because their status is only tenuously guaranteed through employers (Bannerjee 2006) or pending the resolution of humanitarian crisis in the home country (Menjivar 2006). Owing to this on-going fear of deportation, undocumented and legally liminal immigrants rarely make demands for rights or benefits from their receiving state (Horton 2004; Menjivar 2006). When they have made claims, such as during the 2006 immigration protests, they, like documented workers, employ work-based rights frames (Voss and Bloemraad forthcoming) or declarations of a "right to have citizens" rights" (Sassen 2006:1).

Refugees are unique among immigrant groups in the United States in that their incorporation is not solely governed by the labor market. They are also incorporated through the welfare state and are supported by an array of social policies designed to facilitate their adjustment to the receiving society. Although the literature on refugees 
has historically deliberated on the theoretical conundrums posed by a nation-less population (see Malkki 1995, Ong 2003 for critiques), the Vietnamese and Cuban refugees arriving in the United States in the 1980s sparked interest in the process of refugee incorporation (Hein 1992; Pedraza-Bailey 1985; Portes and Bach 1985; Waxman 2001). Like other immigrants, refugees grapple with uneven and contentious reception from their host communities (Fujiwara 2008), and they struggle to understand and respond to the American racial hierarchy (Hein 2006). Yet, although they suffer from serious health and psychological disabilities and have on average low levels of human capital (Ong 2003), refugees engage more in host country politics and naturalize in greater numbers than other immigrants (Bloemraad 2006). These patterns support the segmented assimilationist claim that refugees have adaptational advantages over other immigrants thanks to the federal resettlement assistance they receive (Bloemraad 2006; Portes and Rumbaut 2006; Portes and Zhou 1993).

\section{Citizenship and Claims-Making}

In this paper, I explore a critical facet of refugee incorporation: refugees' views of citizenship and the state. Specifically, I examine how refugees employ their legal status to make claims for social and political membership and to establish their position in the American ethno-racial hierarchy. Existing research offers four distinct conceptualizations of citizenship: citizenship as legal status, citizenship as rights, citizenship as political participation, and citizenship as social belonging (Bloemraad, Korteweg, and Yurdakul 2008). While legal citizenship refers to formal legal membership in a nation-state, rights-based citizenship refers to the obligations states have 
toward residents and political participation to active involvement in governance. The fourth approach, citizenship as belonging, reaches the heart of immigrants' social membership and integration. As Shklar (1998) argues, the struggle for citizenship in the United States has historically been a struggle for social membership more so "than an aspiration to civic participation as a deeply involving activity" (p. 3). A strong sense of social membership has implications for the pursuit and achievement of other types of citizenship from formal rights to legal citizenship status. In this paper, I show how a sense of social membership emerges as refugees make claims for legal and social citizenship rights. ${ }^{i}$

I investigate this citizenship-making process by analyzing the claims refugees make to state agencies for rights, services, and support. I define claims-making as the formal expression of grievances, a process which involves recognizing a problem as a rectifiable grievance and seeking redress from the appropriate individual or authority (Felstiner, Abel, and Sarat 1980). I also argue that immigrant claims are both indicative of and a basis for incorporation. Whether immigrants make claims, how they frame their claims, and what response they receive are all indicators of their political and social membership in a receiving society.

Traditionally, the citizenship literature has analyzed the construction of citizenship at the legislative or policy level. However, recent research suggests that citizenship is in fact given meaning through everyday encounters with the state (Korteweg 2003, 2006; Lipsky 1983). I focus specifically on claims made to "street level" state bureaucrats because they are the most immediate and vital form of claimsmaking for most individuals (Lipsky 1983; Soss 2000). Unlike formal political 
participation (e.g. voting or letter writing) which may produce results months or even years down the line, claims made directly to individual state agents involve pressing personal issues with immediate repercussions. As a result, individuals are more likely to draw conclusions about the state and their relationship to it based on these everyday interactions than they would from other less personal interactions with the state (Lipsky 1983; Soss 2000). Studying claims-making is also empirically advantageous in that such claims involve immediate and observable interactions between individuals and the state. Because these interactions are unscripted, the claims-making frames that individuals use and the reactions they beget from state employees provide a powerful source of data on the immigrant incorporation process.

\section{$\underline{\text { African Immigrants and Refugees in the United States }}$}

This paper focuses specifically on claims-making among African refugees. Over the last ten years, wars in Sudan, Somalia, Ethiopia, Sierra Leone, Liberia, and elsewhere have prompted the resettlement of thousands of African refugees in the United States. Africans are rapidly surpassing Southeast Asians and citizens of the former Soviet Union at the top of U.S. refugee resettlement lists (Batalova 2006; see Figure 1). ${ }^{\text {ii }}$ Unlike other immigrants, refugees travel to the U.S. on airplanes with plane tickets arranged by the U.S. government. They arrive in their host country with guaranteed access to permanent residency and welfare benefits, but resettlement agencies, heeding federal regulations, rapidly steer them toward formal employment, providing job search and English language training. Legally, they are permanent residents from arrival but it can take one or two years to receive their green cards due to bureaucratic delays. They have temporary 
documentation of their legal permanent resident status until green cards arrive. Those wishing to apply for legal citizenship must, as with all legal immigrants, reside in the U.S. for five years before applying and are more likely to apply for citizenship than nonrefugee immigrants (Bloemraad 2006).

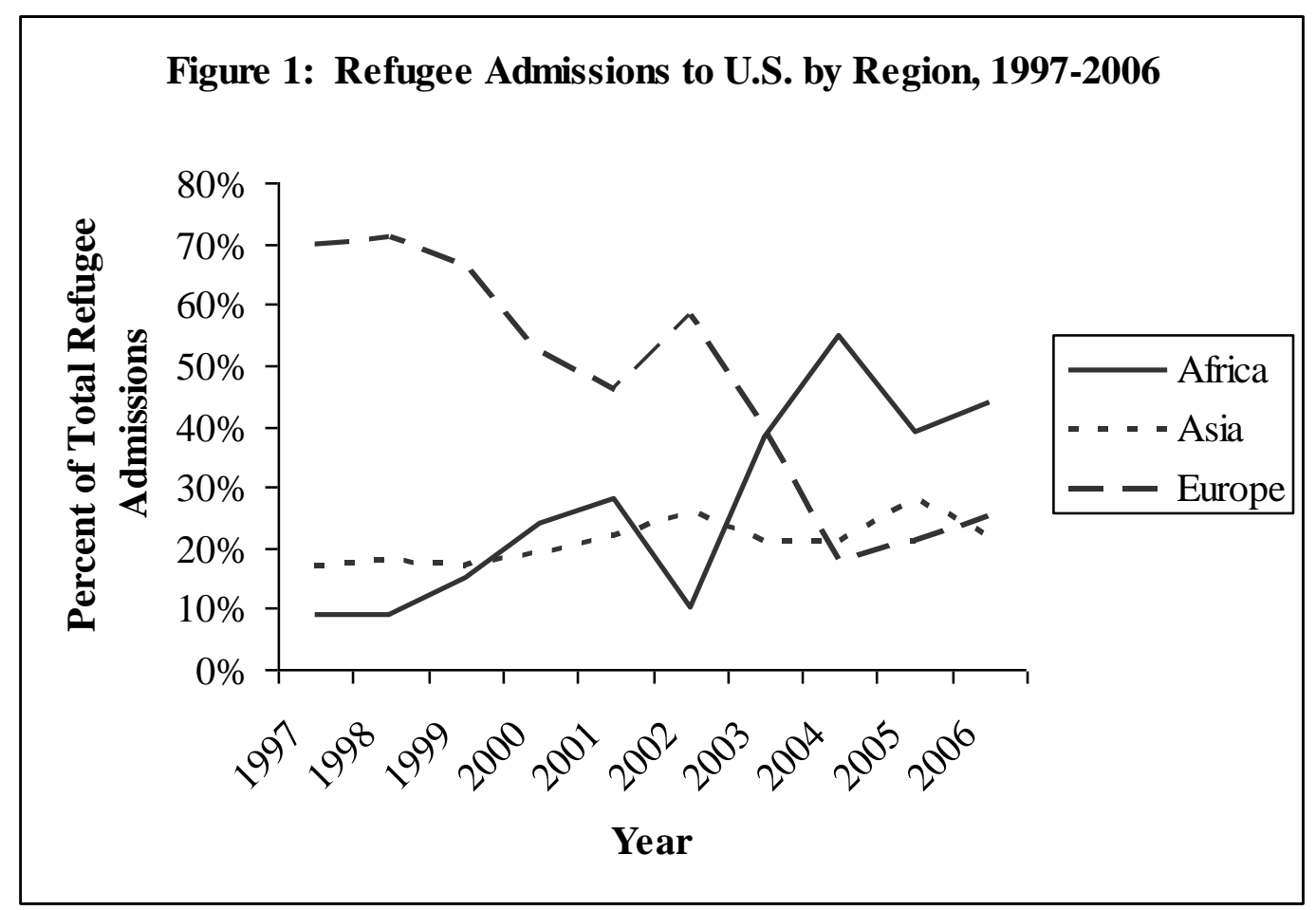

*Data from DHS (2006).

In this study, I draw on participant observation conducted in a Liberian refugee community in California. These Liberian refugees are among the most recent and most disadvantaged groups to resettle in the United States. From 1989 to 2003, a civil war in Liberia displaced nearly one-third of the country's population, forcing over 400,000 people into neighboring countries. Those Liberians who fled to the east landed in Cote d'Ivoire where a civil war erupted in 2002, targeting Liberians who settled in the country (Coulibaly 2004). iii Two years later, the United Nations High Commissioner for Refugees (UNHCR) announced a rapid relocation program which would resettle 7,000 of 
these refugees in the United States and send thousands more to Canada and Europe. By 2003 and 2004, Liberians constituted the second largest group of refugees admitted to the United States (see Table 1). The first wave arrived in the U.S. in May of 2004 with additional groups arriving over the next two years. As with all refugee resettlement endeavors, the Department of Homeland Security assigned each refugee to a Voluntary Agency (VOLAG) or "resettlement agency" which then resettled the refugees throughout the United States. Approximately 500 of the selected refugees landed in California under the auspices of various federally-funded refugee resettlement organizations (ORR 2007).

\begin{tabular}{|cccc|}
\hline \multicolumn{4}{|c|}{ Table 1: Refugee Admissions from Liberia, 1997 to 2006} \\
Year & $\begin{array}{c}\text { \# Liberian } \\
\text { Refugees Admitted }\end{array}$ & $\begin{array}{c}\text { Liberians as \% of Total } \\
\text { Refugee Admissions }\end{array}$ & Rank \\
1997 & 231 & $0.3 \%$ & 9 th \\
1998 & 1494 & $2.0 \%$ & 7 th \\
1999 & 2495 & $2.9 \%$ & 7 th \\
2000 & 2620 & $3.6 \%$ & 11 th \\
2001 & 3429 & $5.0 \%$ & 7 th \\
2002 & 559 & $2.1 \%$ & 10 th \\
2003 & 2957 & $10.4 \%$ & 2 nd \\
2004 & 7140 & $13.5 \%$ & 2 nd \\
2005 & 4289 & $8.0 \%$ & 4 th \\
2006 & 2402 & $5.8 \%$ & 7 th \\
\hline
\end{tabular}

*Data from DHS (2006).

As with many refugee populations, this wave of refugees from Liberia arrived with low levels of human capital. Most of the recent California arrivals, like their counterparts throughout the U.S., lived in extremely rural conditions in Liberia before fleeing to cities in Cote d'Ivoire. Most are illiterate and have no formal education. They arrived in California with few transferable skills and significant health problems. In addition, many were either single mothers whose husbands died during the conflict or 
were grandparents left to raise their grandchildren after their own children, the intermediate generation, perished during the war. Given their situation, many of these individuals rely on disability or welfare benefits to make ends meet. Their day-to-day lives therefore involve regular encounters with state social service and immigration agencies.

\section{Participant-Observation in a Liberian Refugee Community}

In this paper, I draw upon observations gleaned from fieldwork in a Liberian refugee community in a large California city. A local federally funded refugee resettlement agency administered their initial living and housing stipends and helped them search for jobs, enroll in English language programs, and access benefits through the county welfare office. After these refugees began receiving state welfare benefits, county caseworkers displaced resettlement workers as their main lifeline. However, these refugees remained in contact with resettlement agency employees, contacting them on a weekly or monthly basis for assistance with legal citizenship matters, tutoring, and other issues, including help with welfare-related matters. When I began my research, the individuals in this study had been in the Unite States for one to two years. By the end of my fieldwork, most had been in the country for nearly five years.

Upon their arrival in the U.S., the local refugee resettlement agency provided these Liberian families with small apartments in a relatively poor area of the city populated by Spanish-speaking immigrants and Black Americans. ${ }^{\text {iv }}$ Like most resettlement agencies, this agency relies on a specific network of management companies to find rentals for its refugees so as many as twenty refugees often end up living in the 
same small apartment complex. While some of these refugees knew each other in Cote d'Ivoire (where they fled before immigrating to the United States) and others even came from the same villages in Liberia, many met only upon their arrival at the agency their first week in the country. Together, they participated in orientation programs and quickly formed connections with each other, locating the few African grocery stores in the city and joining the one West African-run church in the area. Unlike on the East Coast, there were very few Liberian immigrants in this particular city before these refugees arrived. Thus, their primary ties with their home country were and continue to be through each other. Many of the individuals in the community speak of moving back to Liberia one day and invest what income they have in re-building their home communities. Return is rare, however, given the unstable situation of the country and the fact that they lack formal proof of their Liberian citizenship. ${ }^{\mathrm{v}}$

I began my fieldwork in the community by working as a volunteer with the local refugee resettlement agency. While resettlement agencies provide an array of job assistance, rental assistance, and English language training for newly arrived refugees, they often recruit volunteers to work with families to facilitate their adjustment. Negotiating the ins and outs of life in their new country is particularly challenging. For many refugees, their initial months in the U.S. mark the first time they have had regular access to running water and electricity. After spending their lives in rural villages surrounded by wide swaths of land and forest, they must adapt to living in small cramped apartments in a large urban area.

My work entailed tutoring young children and helping families negotiate complex bureaucracies such as the public health, education, and social welfare systems. I worked 
for eighteen months, spanning 2005 to 2007, with various families in this community, spending on average ten hours per week in their homes and accompanying them to various appointments. I followed this informal participant-observation period with twelve months of formal participant-observation where I closely shadowed twenty-five Liberian refugees and their families. In total, I spent approximately three years in the community. As I expanded my role to a formal participant observer, I spent increasing time in the homes of different families, both as an active participant in their day-to-day lives, engaging in informal conversations and housework, and as an observer, sitting to the side while the families went about their routines. I also accompanied them on their trips to the refugee resettlement office, welfare office, public health clinics, and the social security office. The data presented in this paper thus reflect informal conversations as well as observations of interactions with various arms of the welfare state.

During the course of my research, I took copious field notes and whenever possible, I took notes as events and conversations progressed. Yet at times, particularly during meetings at government agencies, it was not possible to do so. In these cases, I wrote field notes as soon as possible after the interactions occurred. As is generally true with participant-observation research, the results presented in this study emerged from an on-going dialogue with the data. Drawing on existing research in race and citizenship, I used my field notes to identify first the categories and boundaries these individuals used to make sense of their social world (Bell and Hartmann 2007, Eliasoph 1999, Lamont 2000). Secondly, I reassessed the data, noting the specific institutional contexts in which they drew these boundaries. When feasible, I returned to the community to ask questions about my findings, specifically asking about events or comments that seemed to 
contradict prevailing understandings of race and citizenship. This process of dialogue and observation made it possible to explore the boundary-making that occurred in the community and to link specific categories of race and refugee status to constructions of legal and social citizenship.

In the sections that follow, I discuss what meaning refugee status has for these individuals who hold it and, correspondingly, how refugee status shapes their views and expectations of their host country. I present this data in two parts. First, I articulate the subjective construction of refugee status in this particular community and demonstrate how the legal benefits of refugee status, such as the housing, living stipends, and job assistance they receive through refugee resettlement agencies fuel a sense of entitlement for government services and support. In the second part, I shift focus to the racialized model of citizenship expounded in the community. I explore how these individuals situate themselves in the web of American social groups as a means of legitimating themselves as deserving of benefits and care from the state. Rather than make claims based on labor market participation or express fear or ambivalence about the state, these refugees actively make demands for care by citing their nurturing relationships with their families, communities, and the government.

\section{$\underline{\text { Refugee Status, Claims-Making, and Incorporation }}$}

Refugee status has a profound place in the lives of the refugees in this community, particularly in interactions with the state. Indeed, one of the main ways in which these individuals make claims for care and assistance in the United States is by invoking their refugee status. Below, I show that the term "refugee" has two meanings 
for these individuals, both of which encompass more than just documentation status and both of which reference lost relationships. When demanding legal right from the state which proactively resettled them, these individuals use the term "refugee" to reference legal standing and to mean someone who has lost a political-legal relationship with their home country. They argue that the U.S. government should provide for them because the country of Liberia no longer does. When making claims for social rights, they use the term "refugee" as a social welfare status to refer to the affective personal relationships they had with family members in Liberia who were killed during the war. In making these claims, they argue that the American welfare state should assist them because their family members in Liberia cannot. As they strategically employ these two meanings of the word "refugee," the individuals in this study reveal a unique understanding of the citizen-state relationship in the U.S. They view their new legal refugee status as indicative of a specific and very personal relationship with the state, one in which they are entitled to legal and social membership from the government. This sense of entitlement stems directly from the supports they received and messages communicated to them through their early resettlement experience.

\section{Refugee Status and Legal Membership}

The refugee studies literature recognizes the violation of the citizen-state relationship as the defining refugee experience (Malkki 1995; Ong 2003). The Liberian refugees in this city also understand their refugee status in these terms. They frequently assert that being a refugee means lacking protection from a larger political-legal entity, and they use this lack of protection to make claims for rights and services in the U.S. 
This claims-making strategy arises most often when the refugees grapple with the bureaucracies responsible for formal legal citizenship: the immigration office and the refugee resettlement agency. Although refugees arrive in the U.S. with the full rights of legal residents, they must wait upwards of two years to receive their green cards due to processing delays. In the meantime, they have temporary documentation of their permanent residency status. Their temporary paperwork provides a constant source of worry and fear because these refugees encountered massive anti-Liberian sentiment in Cote d'Ivoire where riots targeted them and others who did not having proper immigrant documents. The terms they use to express this concern highlight an understanding that having refugee status means the loss of political and legal protection from their home country.

A particular event illuminates this pattern. In an apartment complex inhabited by nearly twenty Liberian refugees, the wait for green cards generated an atmosphere of fear and angst. With every visit I made over the course of the year, the families in this building grew increasingly concerned with their green cards which, despite assurances from the refugee resettlement agency, had not arrived yet. During this time period, these individuals used every contact they had with a government employee, contractor, or resettlement agent, to demand faster service on their immigration documents. One afternoon, I sat in the living room of one family's apartment, playing with a toddler while his mother spoke on the phone with a resettlement employee. At first she pleaded calmly with the employee, inquiring after her family's documents and expressing her concern. In the middle of the conversation, another adult in the building stopped by and soon five adults from other apartments stood around the phone, demanding their documents. The 
adults from these four families urged the agent, "Why do they make us wait so long? We are refugees, we have no country. We need our cards." In making such claims, these individuals imply that being a refugee implies having "no country," that is, having no political or legal protections from a nation-state. They use this frame to demand assistance from the state with legal citizenship matters.

\section{Refugee Status and Social Membership}

This legal and political relationship with a nation-state is not the only violated relationship that characterizes being a refugee. These individuals also use the term "refugee" to mean the loss of affective personal relationships, that is, relationships with their family members and communities who supported them in Liberia. Fleeing through the forests for weeks at a time during the civil war, these individuals left their friends, churches, and villages behind. Under constant attack from rebel forces, they watched their family members die as they fled. This loss of personal ties and support networks, while a constant emotional struggle, also provides fodder for claims-making in the United States. For example, these refugees typically make demands for social citizenship based on their lost personal relationships, arguing that because they had no family to take care of them anymore, they need help from the welfare state. Speaking of an upcoming appointment with the county social services offices, Alice Sebwe, a Liberian woman in her late fifties, asserted:

"I want to tell the welfare people that I am all by myself. My husband died in the war. My three sons, they were killed in the war... When the war started and all of the men in my life were killed... I put my one child 
on my back, and we ran away. We ran until they [Ivorian officials] told us to stop. Then we came here, but (here) ... I am all alone.”

Alice framed her refugee status in terms of the personal and familial relationships severed by the war in Liberian and her flight to the United States. As with the political relationships lost during the process of becoming a refugee, these lost support networks and relationships are a salient part of her incorporation.

While these individuals draw on their lost legal protections to make claims for legal citizenship, they frame claims for social rights in terms of their lost personal relationships. They feel entitled to benefits from the state not simply because of their lost relationships but because these individuals view the United States as complicit in those losses. Community members regularly argue that President George H.W. Bush had a responsibility to intervene in the Liberian civil war given the historical ties between the U.S and Liberia. ${ }^{\mathrm{vi}}$ They mourn the fact that Bush "just let people die," leaving these refugees with no familial support. For some refugees, the belief that the U.S. government failed to save their relatives is coupled with a feeling that the U.S. government brought them here against their will. Rhoda Vava, an illiterate mother of three whose husband still resides in West Africa, spoke firsthand of this experience. While resettled in Cote d'Ivoire, she signed up for what she thought was an Ivorian ID card, but months later she received the news that she had signed up to go to the U.S. One evening during an informal conversation with two other women, Rhoda explained what came to pass:

Rhoda: "They came back to us, and they said, 'Rhoda, you're going to America.' I said, 'No! I'm not going America. I don't want to go to America. I am staying here.' They said, 'Then why did you put your 
name down to go to America?' I said, 'I put my name down for an ID card, not for going to America.' They said, 'No. You put your name down for America." [She stands up in anger, shaking her fist.] "I did not want to go; no, I did not want to go. So I told my husband, and I told him I'm not going. He told me I have to go, 'Rhoda, you must go.' I said 'No, I'm not going, I'm not leaving this place. He had to beat me to make me come... If he did not beat me, I would not have come to America." Author: "Why did they not let him come with you if he is your husband?" Rhoda: "Because we are not legally married. We are tribally married. We did the ceremony in the village, but we do not have paper to say we are married. So when I go to the [immigration] people to tell them my husband must come to America too, they said he's not your husband, he's your boyfriend."

Rhoda's story reveals her tense relationship with the U.S. government. She feels that the U.S. caused her separation from her husband who she now can reach only by telephone a few times a week. Because the U.S. would not accept her tribal marriage as legally binding, she now struggles to raise three children on her own, one of whom suffers from congenital defects and needed an organ transplant at age two. This interaction reflects a broader narrative in the community in which people view the U.S. government and its policies as complicit in their being refugees at all. They argue to welfare officials and immigration agents that because they have no family and no state, the U.S. government now needs to guarantee their legal and social rights. 


\section{The Refugee-State Relationship}

Being a refugee, in the broadest sense, means a loss of the political legal relationship to one's home country and of the affective personal relationship to one's family and friends. Although these refugees believe that the U.S. government abandoned them during the civil war, this perspective is superseded by the contradictory yet powerful belief that as legal refugees, they are they are respected and valued by the government. They also assert their entitlement to support and benefits from the state by citing their refugee status. This perspective contrasts sharply with that of non-refugee immigrants who legitimize their claims to state support by highlighting their workforce participation (Kurthen 1997; Nakano-Glenn 2004; Voss and Bloemraad forthcoming). In this section, I show that unlike other immigrants, these refugees do not claim to be underappreciated citizen-workers like other documented immigrants (Guevarra 2010, Kurthen 1997, Reese and Ramirez 2002) nor do they experience ambivalence or fear of the state as do undocumented and liminal immigrants (Bannerjee 2006; Menjivar 2006). They believe they are entitled to social and legal rights, perhaps more so than U.S. citizens. They assert that they have a personal rather than bureaucratic or oppositional relationship with the government. Their view of the state as supportive and nurturing stems from their experience of the resettlement process in which the state and resettlement agencies transported them to the U.S. and facilitated their integration. Therefore both the process of becoming a refugee and the initial supports offered to legal refugees provide these individuals with a sense of social membership and encourage claims for assistance and rights. That state agencies respond to these refugee-based claims with additional assistance only furthers the sense of social membership. 
One of the primary pieces of evidence these refugees give for their membership in the U.S. is that the government must value them because it brought them here in the first place. It is common for these refugees to remind government agents of this fact when seeking assistance. Martha Dixon's exit from an abusive relationship provides one of the more poignant examples of the belief that being legal refugees proves that the government values them. For nine months, Martha, a single mother in her twenties, had been in a relationship with an abusive American man. He would lock her in his house for days at a time, beat her, and threaten to kill her if she left him. One evening, Martha and I sat together in her bedroom as she updated me on the details of her life after we went for a few months without seeing each other. Her eyes ablaze and fists clenched, she told me that after a particularly harsh beating, her abuser:

"said, 'You dirty African woman, you have no power in my country.' I said, 'I have more power than you do! I'm a refugee. Your government brought me here. Your government knows all about me. It has all my information. If you do something to me, the government will know that it was you. You think you have power? Power over me? You can call the police but $I$ have the whole American government on my side. I have more power than you!'

After making this declaration, Martha immediately picked up the phone to call the police. They arrested her abuser that night, and Martha has not seen him since. Her story reveals her conviction that being a refugee entitles her to care from the state and that the state will provide her with that protection. The collection of immigration documents she mentions offer proof that the government watches out for refugees and will assist them even if it 
means arresting a U.S. citizen. Her characterization of her relationship with the U.S. government offers a potent example of the care these refugees believe they deserve (and get) and the role of refugee status in their claims-making. While other non-refugee immigrants use their employment to make claims on the state, Martha references her refugee status. Typical in the community, these individuals directly reference their refugee status because it conveys to them and, they believe, to the state their social membership.

In a less dramatic fashion, this same sentiment that the state values refugees arose in a conversation with two women one evening. Given their illiteracy, these Liberian refugees rely on refugee resettlement staff and volunteers to read their mail for them. As a volunteer and subsequently as a participant-observer, I frequently filled this role for families. One evening, I sat on the couch in an apartment that two families shared and read aloud their letters. After opening several letters for each woman (including a child's report card, bank statements, and reminders for medical appointments) and explaining the content, I commented to the women that they received a great deal of mail. "I don't get this many letters. Why do you get so many?" One of the young single mothers replied, "We are refugees. That is why we get so much mail. The government is checking up on us." These individuals assert that refugees get more mail than American citizens because the U.S. government cares for them enough to check on them by sending letters. Again, this sense of social membership contrasts starkly with the perspective of undocumented immigrants and legally liminal immigrants who feel undervalued and even threatened by the state. 
Thus not only does their legal refugee status feature prominently in the claims these refugees make to immigration and resettlement officers, welfare officials, and police, these refugee-based claims reflect a sense of entitlement to government assistance based on their early resettlement experience. This process (particularly the fact that the government brought them here and provided them with support) communicated to these refugees that they are valued and respected members of U.S. society, perhaps even more valued than legal citizens. In using their refugee status to make claims for assistance, these individuals anticipate that asserting their refugee status to others will bring rewards. Indeed, in many instances, it does. For example, unlike most other welfare recipients, these individuals are often greeted with smiles and hugs by their caseworkers. Many successfully use their refugee status to negotiate with their caseworkers for rule exceptions or to arrange for transportation to appointments. When filling out forms for government services, resettlement workers even tell these individuals to write "REFUGEE" in bold letters on their applications because they will be more likely to get services. $^{\text {vii }}$

Additionally, these refugees view their relationship with their host government as a new relationship, one that is both personal and political, that replaces those they have lost. This view of the government contrasts sharply with that of most welfare recipients who view government assistance as a chain of bureaucratic loopholes and aggravations (Soss 2000). In their daily claims-making practices, these refugees argue that they deserve assistance because of their lost relationships with Liberia and their families. They see refugee resettlement employees, welfare employment officers, and other government agents as replacing those lost relationships. John Jefferson, a Liberian man 
in his forties with more education than most refugees shared a commonly voiced sentiment that, "in America you need to rely on the government to care for you because people do not care about each other here... in America, the people are so individualistic that the government has to look out for people."

Not only have refugees lost their own personal networks, the primary way they can build new relationships in the U.S. is with the state that cares for them. Refugees cultivate relationships with welfare employment officers and express grave concerns when their officers leave the job or when their case gets transferred to a new officer. They worry when they do not have one doctor with whom they can build a relationship. Like many citizen welfare recipients, they cannot read or fill in the forms and rely on welfare employees or resettlement workers to sit down with them and engage in conversation. Yet rather than view this questioning as invasive as do citizen welfare recipients (Soss 2000), they interpret this conversation as the formation and sustenance of a new affective personal relationship. Receiving welfare assistance therefore entails not a demeaning series of bureaucratic interventions but a process of dialogue, of relationship building, and of care giving with the state. The very act of engaging with caseworkers reaffirms their sense of social membership, and their belief that they have a unique relationship with the state is further evidence of the effect of their the early migration experiences on their incorporation. That these individuals often do receive special benefits and services suggests that state bureaucrats may share this belief about refugee entitlement.

\section{$\underline{\text { Race and Citizenship }}$}


The above section highlights the salience of legal refugee status to those who hold it. Refuges status is a resource for these individuals as they make claims for legal and social citizenship in the United States. In this section, I show that these individuals also use their refugee status to situate themselves in a broader matrix of American citizenship. Just as they understand refugee status in terms of relationships so too do they understand citizenship and social membership. Being Liberian means participating in relationships of care which also makes Liberians constructive and deserving members of society. This process of self-definition is highly racialized. That is, these individuals use their refugee status not only to make claims on the state but to differentiate themselves from Black Americans whom they view as failed citizens and to establish their place in the American ethno-racial hierarchy.

The study of racialization, the creation and imposition of ethno-racial categories, has typically focused on native-born Black and White Americans; however, immigration to the United States is changing the use and meaning of ethno-racial categories (Omi and Winant 1994; Kasinitz 2004). Shifts in immigration patterns, such as rising levels of immigration from Africa, ${ }^{\text {vii }}$ are altering the process of racial formation, "the sociohistorical process by which ethno-racial categories are created, inhabited, transformed, and destroyed" (Omi and Winant 1994:9) and changing what it means to be “Black” or "African” in a U.S. context (Waters 1999; Arthur 2000; Roberts 2005). Extant research on the Black foreign-born focuses heavily on the labor market incorporation experiences of West Indian immigrants, attempting to explain their disproportionate economic achievements when compared to native-born Blacks (Glazer and Moynihan 1963; Steinberg 1989; Modell 1991; Waters 1999). Although early 
literature on Black immigrants attributes these successes to positive cultural values, more recent scholarship asserts the primacy of network hiring practices, ethnic niches, and employer preference for foreign-born employees (Steinberg 1989; Waters 1999).

Employers view Black immigrants as harder workers and better employees than nativeborn Blacks. In turn, Black immigrants recognize that assimilation into Black America means both economic and social downward mobility (Waters 1999). Some news media reports indicate that African refugees are particularly hostile toward Black Americans (Sanders 2010). As a result, these refugees work to maintain their status as foreigners, emphasizing their accents, wearing clothes from their home countries, and cultivating their networks with other foreign-born Blacks (Waters 1999; Arthur 2000). The gender and class backgrounds of these individuals as well as the ethno-racial hierarchies of the host society shape their economic incorporation and the likelihood that they will maintain a foreign-born identity in the second generation (Waters 2001; Model 2005; Kasinitz et al 2009).

Given these findings, it is not surprising that the African refugees in this study attempt to distance themselves from native-born Blacks when they make claims to government agencies and volunteers. What is surprising is the narrative framework they use to build this distance. Studies reveal that Black foreign-born workers view nativeborn Blacks as lazy and mediocre workers. By making these claims, foreign-born Blacks define themselves as worthy of labor market advantage (Waters 1999). However, it is much harder for non-working and welfare-reliant Black foreigners to make this distinction. In order to distance themselves from native-born Blacks, these Liberians rely on narratives of citizenship that mirror their constructions of refugee status. They equate 
citizenship or social membership with attention to and participation in relationships of care, defining themselves as quintessential Liberians who honor relationships. Through this discourse, and a countervailing discourse which portrays Black Americans as alienated from relationships of care, they legitimate their entitlement to benefits and support from the state. Furthermore, as Omi and Winant (1994) would suggest, the discursive characterizations of Black Americans employed by these immigrants arise from the racially patterned structural arrangements they encounter in everyday life. In this case, living in residentially segregated low-income communities with high crime rates and a large Black population fuels anti-Black sentiment and racial distancing. ${ }^{\mathrm{ix}}$

That personal and civic relationships figure prominently in these constructions of citizenship harkens back to the constructions of refugee status discussed in the last section. While the loss of a political-legal relationship with one's country of origin characterizes refugee status for these individuals, a positive and constructive relationship with one's country characterizes a good citizen. For example, these refugees typically espouse their proud history as state-builders and as productive citizens to make claims for assistance in the United States. They take great pride in the fact that Liberians "built our country ourselves" while every other African country needed help from a colonial power. In discussing the 2006 Liberian elections in which the country became the first in Africa to elect a woman president, these refugees characteristically cited Liberia's independence and self-sufficiency regardless of their views on the election results. Those pleased with the election of President Ellen Johnson Sirleaf argued that Liberians were once again showing the way in Africa, following their long history of self-governance and statebuilding. Those upset with Sirleaf's election criticized her response to the civil war as 
anti-Liberian, failing to live up to the Liberian tradition of interdependence. As one man stated,

"We built our country ourselves, you know. Everywhere else in Africa the White people built the country. But we built Liberia ourselves....And the new president, she is no good, that woman. One year [in office] and she's done nothing. She asked America and other people for help, for money, to rebuild. She asked here and there. But what does she want? We did this to ourselves. If Liberia and Ivory Coast fight, then you can ask for money to rebuild. But Liberians fighting themselves? How we can ask for help? When you go into your own house, you break all the tables, you break all the chairs, you break all the beds. Then you ask someone to help you buy new things? They're not going to help you. You need to fix it yourself."

He, like other Sirleaf detractors, went on to praise George Weah, a former member of the national soccer team and the opposing candidate in the 2006 elections, for using his own money to rebuild the country and to engage Liberian citizens in the rebuilding process. Weah's strategy reflected the pride these Liberians have in the country they built for themselves. These statements about Sirleaf's reconstruction strategy also reflect the extent to which these individuals view their relationship to their country as a familial relationship. By comparing his country to a household, this man signals the centrality of interdependence and strong relationships for citizenship.

Not only do these Liberian refugees pinpoint a positive citizen-state relationship as a prerequisite for receiving state support, they also identify strong interpersonal 
relationships as characteristics of a good citizen. On the whole, the Liberians in this California city are constantly concerned with sending money back to Liberia. They view these remittances not only as an economic lifeline for their families in Liberia but also as a means of nurturing their relationships with people back home. This pattern appears most strongly when these individuals argue that Liberians support each other through strong social networks. In such narratives, these individuals generally assert that in Liberia, churches help people, and people help each other. When someone needs money, food, or other assistance, friends and family will help him without even asking questions. If people are traveling and come to a village needing food, the people will feed them, whether they know them or not. Thus, when discussing their encounters with others in the United States and in West Africa they say that no matter the situation, if you are in trouble, "Liberian people will help you." Said one elder in the community, "If you have a problem, you come talk to me... We do things together. We work together. We laugh together. We are united." Another man summarized this same sentiment by saying, "In Liberia, churches, communities, and villages look out for the people, for each other." These narratives of interdependence contrast starkly with their portrayal of life in the U.S. Americans, as John Jefferson lamented in the last section, only need the police and the government because the people do not care about and do not take care of each other.

These individuals thus use their refugee status to interpret and convey Liberian cultural practices in order to legitimize themselves as citizens in the United States and to buttress their standing in the eyes of state employees. They use their participation in caring relationships in the United States to the same end, investing significant time, money, and energy into fortifying the relationships which they believe make them ideal 
citizens in the eyes of their new government. This attention to relationships with people reveals itself in day to day life. These Liberian refugee families typically bring home enormous bags of rice from the grocery store, explaining that they must always be prepared to feed more mouths than just their own. When guests, strangers, or anyone in need comes to your house, said Cheryl Kromah, a non-working woman in her sixties, you must be ready to feed them: "That's what we do, my people," she proclaimed, proudly patting her chest. Not only do families stockpile rice to feed others, they give generously to beggars and homeless people on the streets, despite their own financial struggles. It is not uncommon for a Liberian in this community to mention giving five dollars or ten dollars to a beggar on the street. Moreover, they poke fun at the Americans who shrink to the other side of the sidewalk when encountering a homeless person. In a number of small hair braiding stores in the city where Liberian women work under the table to supplement their welfare benefits, the women continue the West African tradition of sousou, collecting money in a communal pot for a given period of time and then turning the money over to one of the women. The tradition, according to these women, embodies Liberian ideal of interdependence and care.

According to these community members, strong caring relationships define them as good citizens both in their own eyes and in the eyes of the state. Yet these individuals do not make these positive claims of citizenship and personhood in a vacuum. Rather, they make them in the context of a racialized construction of social membership. The Liberian refugees in this community continuously juxtapose their own "Liberian" priorities and actions with those of Black Americans. ${ }^{\mathrm{x}}$ They make a conscious effort to 
distance themselves from native-born Blacks, listing themselves as "Liberian" on government forms, saying "I don't like to say that I am Black."

As they draw these boundaries, relationships and caring again take center stage. While research on employed West Indian immigrants emphasizes the labor-related classifications they use to distinguish themselves from Blacks, the Liberian refugees in this study focus on relationships as a means of distinction. According to their selfcharacterizations, these refugees have positive caring relationships with both their country and with other people. By contrast, they see Black Americans as having negative relationships both with their country and their fellow Americans. This rhetoric reflects the structural conditions in which these refugees live. Most live in impoverished, predominantly African American neighborhoods in this city. While these individuals arrived in the U.S. expecting to have strong relationships with Black Americans given that Black Americans founded the Liberian government, their sense of connection quickly dissolved as many experienced violence and theft at the hands of Black Americans. Stories of knife attacks, beatings, theft, and other crimes circulate through the Liberian community, and individuals quickly began expressing disdain for Black Americans. Fears of Black Americans were only amplified by the large number of Black panhandlers on the streets in their neighborhoods.

As a result of these conditions, the individuals in this study view Black Americans as selfish, exploitative of strangers, and lazy individuals who do not respect their country. In their eyes, because Black Americans have failed to maintain caring relationships, they have failed at the basic task of citizenship. ${ }^{\mathrm{xi}}$ The belief that Black Americans fail to build 
a strong relationship with their country surfaces quite potently in a diatribe from Rhoda Vava:

“But you know about Black people. They're no good. They're just trouble. They are always making trouble for people, taking money, asking for money. They're no good. They not working, they only take people's things. This is their country and they're not working! How you can not work in your own country?"

Although Rhoda's discussion of work appears similar to the work-based boundaries drawn by West Indian immigrants, her final statement, "How you can not work in your own country?" indicates that she views working not as necessary for self-sufficiency or independence. Rather, working is a means of showing respect for or demonstrating a good relationship with your country. Her comments reveal her belief that Black Americans have a poor relationship with both their country and their fellow citizens. Rather than work as a means of assisting and showing pride in one's country, Black Americans, in Rhoda's eyes, simply beg and exploit the generosity of others. Rather than ask for help from family or friends, they steal, violating the social relationships that she and her fellow Liberians view as critical to social membership. Through these distinctions and narratives, these community members not only construct a negative view of Black citizenship, they distinguish themselves as productive Liberian citizens. These stories and claims thus serve the dual purpose of distancing them from Black Americans and setting the stage for the refugee-based claims they make on the agencies and individuals that assist them. 
As outlined above, the negative construction of Black citizenship reveals itself through direct accusations but also in daily conversation. When they meet a Black homeless person on the street who is asking for money, they interpret this interaction as proof that Blacks on the whole do not have enough respect for their country to work. These themes arose one evening when one woman told her housemates of her encounter with a Black beggar on the street that day:

That man he come up to me on the street again today. He wanted money.. I said, "Why do you ask me for money and not other people? It because you remember me, because I gave you money last time, right?” And downtown, the people ask me for money, too. The dirty Black lady and her baby. And the homeless man. He came to me and asked me for money. He said, "Oh, I am hungry. I've not eaten since yesterday." I said, to him, "Why you ask me? This your country, why you asking me for help?"

Following this remark, she did give the man five dollars. When I asked her why she gave him the money after chiding him for not working she said, "I help people in America because I know what it is like when you have nothing and people help you." Another woman elaborated further on that remark saying that she, too, gave money to people on the street. She said,

I give a lot of money to people on the street in America. Just up the street near Safeway I gave somebody $\$ 2$. I give a lot of money. Because, you know, I have to help them. That what we do ... Liberian people will help you. They don't look away. 
The exchange thus creates and reinforces a racialized view of deservingness and entitlement. The Black man's begging and that of the "dirty" Black woman signify to this Liberian woman his failed relationship with his country and reinforces for Rhoda the idea that Blacks take but do not give. That these women give money to beggars regardless of this fact, however, reasserts their own her own deservingness as citizens. They, like others, use these encounters with Black homeless people both to degrade a perceived Black model of citizenship and to bolster their own Liberian refugee variation, widening the gap between Liberians refugees and American Blacks while reaffirming themselves as responsible and deserving refugees.

Not only do individuals in this community see Black Americans as unwilling to engage in and maintain positive relationships, they also see them as relying too heavily on welfare and other forms of government assistance. The welfare office frequented by these and other refugees in the city is located in a predominantly Black area and the clientele reflects these demographics. Upon walking into this office, many Liberian refugees shake their heads at the large numbers of Black women in the waiting area and say, "Why do Black people like welfare so much? They don't like to work." Reliance on welfare in this instance further signifies that Black Americans take more than they give. It is this argument specifically upon which these Liberian refugees build their own claims for assistance and justify their own non-work and welfare reliance. Like these individuals, non-refugee welfare recipients legitimize their own use of welfare by making distinctions with other recipients who they see as lazy or abusing the system (Little 1999; Woodward 2008). In finding opportunities for resistance in the welfare office they complicate narratives about welfare and dependency (Fraser and Gordon 1994). In the 
case of these refugees, however, legitimizing their use of welfare involves drawing boundaries between themselves and Black Americans who they believe deserve little public assistance because they have violated so many critical relationships with their welfare employment officers, their government, and others. Liberian refugees, on the other hand, deserve assistance from the state because they cherish relationships and work hard to build and sustain them. Indeed, while they define Black Americans' reliance on welfare as a violation of a relationship, Liberian refugees see their reliance on welfare as necessary for the sustenance of their personal relationships and their relationship with the government that cares for them. Additionally, unlike Black Americans who fail "their own country," Liberian refugees are here for the first time and need the chance to go to school, to "grow their minds" before they can take on work. ${ }^{\text {xii }}$

The discursive separation these individuals create between themselves and Black Americans is extensive. In the process of conducting this research, I, a White woman, had families call to request my help with certain tasks because they did not trust a Black volunteer: "He's not White," they said. "He's Black; we don’t trust him." When they had positive encounters with Black Americans, such as with a particular nurse at the local hospital, they described these individuals as exceptions to the rule ("Yes, she's Black but she's not like most Black people.") That their everyday lives, from neighborhoods and welfare offices to crime and poverty, are structured by race prompts a visceral desire to differentiate themselves from Black Americans and to categorize everyone with whom they come into contact. Given the historical ties between Liberians and Black Americans and the expectations these Liberian refugees had for strong personal relationships with Black Americans in the United States, their efforts to distance themselves provide 
striking evidence of the enduring importance of race to American citizenship and belonging. Furthermore, these race-based claims and the refugee-based claims offer further evidence of the centrality of relationships in these refugees' view of the state.

\section{Conclusion}

By interrogating the claims-making strategies of legal refugees, this study reveals that refugee status has meaningful and consequential effects on refugees' incorporation. The refugees in this study interpret the material supports given to them through resettlement programs as evidence of their social membership in the United States. They use their refugee status to make claims for legal and social citizenship. In doing so, they cite their legal status as evidence of a strong relationship with the United States government and reframe reliance on government programs in terms of personal relationships with caseworkers and with the state. They also use their refugee status to establish their position in the American ethno-racial hierarchy. Unlike other Black immigrants who highlight their work-ethic to distance themselves from native-born Blacks, the individuals in this community erect such boundaries by alluding to their refugee status. That refugee-based claims so often bring them the benefits and services they seek only fuels the on-going use of these claims-making strategies. Being a refugee, therefore, is more than just a documentation status for these individuals. It is a resource employed in the incorporation process.

Unveiling the claims-making strategies of refugees complicates our understanding of immigrant incorporation and adaptation. These refugees' sense of citizenship and social membership reveal a fundamentally different notion of the citizen-state 
relationship that appears in existing research. Studies currently highlight the fear or ambivalence with which undocumented or legally liminal immigrants approach the government (Coll 2004; Menjivar 2006) or report that immigrants frame their claimsmaking in terms of labor market participation (Voss and Bloemraad forthcoming). Rather than experience on-going ambivalence about their position in the eyes of their receiving country, the refugees in this study assert a strong personal relationship with their host government and with its local offices and employees. Rather than view their relationship with the state as a bureaucratic or threatening one, they see their daily interactions with the state in terms of personal relationships of care and support. The resettlement process itself provides these refugees with evidence that their host government values and respects them. Whereas undocumented or liminal immigrants struggle to receive demanded services or rights from the government (Horton 2004; Menjivar 2006; Voss and Bloemraad forthcoming), the refugees in this study are much more successful in garnering rights and benefits. Therefore, this sense of refugee citizenship and social membership has significant effects on these refugees' encounters with major institutions and, ultimately, their incorporation.

These findings highlight the importance of analyzing immigrant incorporation from a micro perspective. A micro-level analysis redirects our attention from economic incorporation to legal status as a symbolic and interpretive resource used to negotiate the structural realities of life in the receiving society. This study also uncovers the sources of African refugees' resentments toward Black Americans (Sanders 2010) and the rhetorical strategies they use in racial distancing. As a result, these findings speak to the effect of recent immigration shifts on the American race relations. 
In breaking down the dichotomy between documented and undocumented immigrants, this study also suggests that privileges afforded to and restrictions placed upon individuals through their specific legal status have profound implications for the immigrant incorporation process. The positive relationship that these refugees have with the state likely accounts for some of the adaptational advantages refugees are found to have in existing research (Bloemraad 2006; Portes and Rumbaut 2006; Portes and Zhou 1993). Indeed, these results indicate that resettlement assistance may have large scale symbolic and material implications for immigrants. If the "refugee" category and the benefits that accompany it help individuals form a positive association with their host state, it may be possible to tailor immigration policies to encourage the formation of strong citizen-state relationships and to facilitate immigrants' social and political incorporation. The task of future research is to enhance our understanding of the immigrant-state relationship by analyzing the effects of other legal statuses and programs on immigrants' lives and to examine the long-term consequences of these state categories and programs for immigrant incorporation and mobility. 


\section{$\underline{\text { References }}$}

Arthur, John. 2002. Invisible Sojourners: African Immigrant Diaspora in the United States. Westport: Praeger.

Banerjee, Payal. 2006. "Indian Information Technology Workers in the United States: The H-1B Visa, Flexible Production, and the Racialization of Labor." Critical Sociology $425-445$.

Batalova, Jeanne. 2006. "Spotlight on Refugees and Asylees in the United States." Migration Information Source. Washington, DC: Migration Policy Institute. http://www.migrationinformation.org/USFocus/display.cfm?ID=415.

Bell, Joyce M., and Douglas Hartmann. 2007. "Diversity in Everyday Discourse: The Cultural Ambiguities and Consequences of Happy Talk.” American Sociological Review 72:895-914.

Bloemraad, Irene. 2006. Becoming a Citizen: Incorporating Immigrants and Refugees in the United States and Canada. Berkeley: University of California Press.

Bloemraad, Irene, Anna Korteweg, and Gökçe Yurdakul. 2008. “Citizenship and Immigration: Multiculturalism, Assimilation, and Challenges to the NationState." Annual Review of Sociology 34: 153-179.

Coll, Kathleen. 2004. “Necesidades y Problemas: Immigrant Latina Vernaculars of Belonging, Coalition, and Citizenship in San Francisco, California.” Latino Studies 2:186-209.

Coulibaly, Loucoumane. 2004. "Thousands of Liberian Refugees to Resettle in U.S." Washington Post. Washington, DC. 
Department of Homeland Security (DHS). 2006. Handbook of Immigration Statistics. Washington, DC: Department of Homeland Security.

Eliasoph, Nina. 1999. “"Everyday Racism" in a Culture of Political Avoidance: Civil Society, Speech, and Taboo.” Social Problems 46:479-502.

Esping-Anderson, Gosta. 1990. The Three Worlds of Welfare Capitalism. Princeton: Princeton University Press.

Espiritu, Yen Le. 1992. Asian American Pan-ethnicity: Bridging Institutions and Identities. Philadelphia, PA: Temple University Press.

Felstiner, William L.F., Richard L. Abel, and Austin Sarat. 1980. “The Emergence and Transformation of Disputes: Naming, Blaming, Claiming...." Law and Society Review 15:631-654.

Fraser, Nancy, and Linda Gordon. 1994. "A Genealogy of Dependency: Tracing a Keyword of the U.S. Welfare State.” Signs 19:309-336.

Fujiwara, Lynn H. 2005. "Immigrant Rights Are Human Rights: The Reframing of Immigrant Entitlement and Welfare.” Social Problems 52:79-101.

Fujiwara, Lynn. 2008. Mothers without Citizenship: Asian Immigrant Families and the Consequences of Welfare Reform. Minneapolis, MN: University of Minnesota Press.

Gans, Herbert. 1992. "Ethnic Invention and Acculturation: A Bumpy-Line Approach.” Journal of American Ethnic History 12:42-52.

Glazer, Nathan and Moynihan, Daniel P. 1963. Beyond the Melting Pot: The Negroes, Puerto Ricans, Jews, Italians and Irish of New York City. Cambridge, MA: MIT Press. 
Guevarra, Anna Romina. 2009. Marketing Dreams, Manufacturing Heroes: The Transnational Labor Brokering of Filipino Workers. Rutgers University Press. Hein, Jeremy. 1992. States and International Migrants: The Incorporation of Indochinese Refugees in the United States and France. Westport, CT: Westview Press.

Hein, Jeremy. 1993. "Refugees, Immigrants, and the State.” Annual Review of Sociology 19:43-59.

Hein, Jeremy. 2006. Ethnic Origins: The Adaptation of Cambodian and Hmong Refugees in Four American Cities. New York, NY: Russell Sage Foundation.

Horton, Sarah. 2004. "Differential Subjects: The Health Care System's Participation in the Differential Construction of the Cultural Citizenship of Cuban Refugees and Mexican Immigrants." Medical Anthropology Quarterly 18:472-489.

Kasinitz, Philip, John H. Mollenkopf, Mary C. Waters, and Jennifer Holdaway. 2008. Inheriting the City: The Children of Immigrants Come of Age. Cambridge, MA: Harvard University Press.

Korteweg, Anna C. 2003. "Welfare Reform and the Subject of the Working Mother: "Get a Job, a Better Job, Then a Career".” Theory and Society 32:445-480.

Korteweg, Anna C. 2006. "The Construction of Gendered Citizenship at the Welfare Office: An Ethnographic Comparison of Welfare-to-Work Workshops in the United States and the Netherlands." Social Problems 13:314-340.

Lamont, Michele. 2000. The Dignity of Working Men: Morality and the Boundaries of Race, Class, and Immigration. Cambridge, MA: Harvard University Press. 
Levitt, Jeremy. 2005. The Evolution of Deadly Conflict in Liberia: From

'Paternaltarianism' to State Collapse. Durham: Carolina Academic Press.

Lipsky, Michael. 1983. Street Level Bureaucracy. New York, NY: Russell Sage

Foundation.

Loveman, Mara. 1999. “Is "Race" Essential?” American Sociological Review 64:891-898.

Malkki, Liisa H. 1995. Purity and Exile: Violence, Memory, and National Cosmology among Hutu Refugees in Tanzania. Chicago, IL: University of Chicago Press.

Marshall, T.H. 1963. Class, Citizenship, and Social Development. New York: Doubleday.

Marx, Anthony. 1998. Making Race and Nation: A Comparison of the United States, South Africa, and Brazil. Cambridge, UK: Cambridge University Press.

Massey, Douglas S., Jorge Durand, and Nolan J. Malone. 2002. Beyond Smoke and Mirrors: Mexican Immigration in an Era of Economic Integration. New York: Russell Sage Foundation.

Massey, Douglas S., Luin Goldring, and Jorge Durand. 1994. "Continuities in Transnational Migration: An Analysis of Nineteen Mexican Communities." American Journal of Sociology 99:1492-1533.

Menjivar, Cecilia. 2006. 'Liminal Legality: Salvadoran and Guatemalan Immigrants' Lives in the United States.” American Journal of Sociology 111(4): 999-1037.

Model, Suzanne. 1991. "Caribbean Immigrants: A Black Success Story?” International Migration Review 25:248-276.

Model, Suzanne. 2005. "Non-white Origins, Anglo Destinations: Immigrants in the US and Britain." Pp. 363-392 in Ethnicity, Social Mobility, and Public Policy: 
Comparing the USA and UK, edited by Glenn C. Loury, Tariq Modood, and Steven M. Teles. Cambridge, UK: Cambridge University Press.

Nakano-Glenn, Evelyn. 2004. Unequal Freedom: How Race and Gender Shaped American Citizenship and Labor. Cambridge: Harvard University Press.

Office on Refugee Resettlement (ORR). 2007. "Refugee Arrival Data." Retrieved January 10, 2008 (http://www.acf.hhs.gov/programs/orr/data/refugee_annual_data.htm).

Ong, Aihwa. 2000. Flexible Citizenship: The Cultural Logics of Transnationality. Durham: Duke University Press.

Ong, Aihwa. 2003. Buddha is Hiding: Refugees, Citizenship, the New America. Berkeley: University of California Press.

Pedraza-Bailey, Silvia. 1985. "Cuba's Exiles: Portrait of a Refugee Migration.” International Migration Review 19:4-34.

Phillips, Julie A., and Douglas S. Massey. 1999. “The New Labor Market: Immigrants and Wages after IRCA.” Demography 36 (2): 233-46.

Portes, Alejandro. 2006. "Paths of Assimilation in the Second Generation." Sociological Forum 10(21): 499-506.

Portes, Alejandro, and Robert L. Bach. 1985. Latin Journey: Cuban and Mexican Immigrants in the United States. Berkeley, CA: University of California Press.

Portes, Alejandro, and Ruben G. Rumbaut. 2006. Immigrant America: A Portrait. Berkeley: University of California Press. 
Portes, Alejandro, and Min Zhou. 1993. "The New Second Generation: Segmented Assimilation and Its Variants." Annals of the American Academy of Political and Social Science 530:74-96.

Reese, Ellen, and Elvia Ramirez. 2002. "The New Ethnic Politics of Welfare: Struggles Over Legal Immigrants' Rights to Welfare in California." Journal of Poverty 6:29.

Roberts, Sam. 2005. "More Africans Enter U.S. Than in Days of Slavery." New York Times. New York, NY.

Roediger, David R. 1991. The Wages of Whiteness: Race and the Making of the American Working Class. London: Verso.

Salcido, Olivia, and Madelaine Adelman. 2004. “"He Has Me Tied with the Blessed and Damned Papers: Undocumented-Immigrant Battered Women in Phoenix, Arizona." Human Organization 63 (2): 162-72.

Sanders, DaVaun. 2010. “Arizona’s Other Immigrant Conflict: African Americans vs. Africans - New America Media.” Retrieved July 23, 2010 (http://newamericamedia.org/2010/07/arizonas-other-immigrant-conflict-africanamericans-vs-africans.php).

Sassen, Saskia. 2006. "The Bits of a New Immigration Reality: A Bad Fit with Current Policy." Retrieved March 26, 2010 (http://borderbattles.ssrc.org/Sassen/).

Smith, Michael P. 1994. "Can You Imagine? Transnational Migration and the Globalization of Grassroots Politics.” Social Text 39:15-35.

Soss, Joe. 2000. Unwanted Claims: The Politics of Participation in the U.S. Welfare System. Ann Arbor: University of Michigan Press. 
Soysal, Yasemin Nuhoglu. 1995. Limits of Citizenship: Migrants and Postnational Membership in Europe. University of Chicago Press.

Speer, Tibbett. 1994. “The Newest African Americans aren't Black.” American Demographics 16(1):9-10.

Steinberg, Stephen. 1989. The Ethnic Myth: Race, Ethnicity, and Class in America. Boston: Beacon.

Terrazas, Aaron. 2007. "African Immigrants in the United States." Migration Information Source. Retrieved February 22, 2010 (http://www.migrationinformation.org/USfocus/display.cfm?id=719).

Voss, Kim and Irene Bloemraad, eds. Forthcoming. Rallying for Immigrant Rights. Berkeley: University of California Press.

Wacquant, Loic J.D. 1997. "For an Analytic of Racial Domination." Political Power and Social Theory 11:221-234.

Waters, Mary. 1999. Black Identities: West Indian Immigrant Dreams and American Realities. New York: Russell Sage.

Waters, Mary C. 2001. "Growing Up West Indian and African American: Gender and Class Differences in the Second Generation.” Pp. 193-215 in Islands in the City: West Indian Migration to New York, edited by Nancy Foner. University of California Press.

Waxman, Peter. 2001. "The Economic Adjustment of Recently Arrived Bosnian, Afghan and Iraqi Refugees in Sydney, Australia." International Migration Review 35:472-505. 
Wells, K.R. 2008. “Liberian Americans.” Every Culture. Retrieved June 20, 2009 (http://www.everyculture.com/multi/Le-Pa/Liberian-Americans.html)

Woodward, Kerry. 2008. "The Multiple Meanings of Work for Welfare-Reliant Women." Qualitative Sociology 31:149-168. 
$\underline{\text { Notes }}$

${ }^{\mathrm{i}}$ Following T.H. Marshall (1963), I define social citizenship rights as the right to economic security and social welfare.

ii The number of African immigrants to the United States has also increased dramatically since the 1990s. African immigrants now make up nearly $4 \%$ of the immigration population in the United States as compared to $1.8 \%$ in 1990 (Terrazas 2007). As of 2005, there were approximately 61,000 Liberian-born Blacks in the United States, according to the American Community Survey, but Liberian community organizations place the full estimates of Liberian-born immigrants in the U.S. at between 250,000 and 500,000 (Wells 2008).

iii While most countries in Africa have a formal refugee policy allowing the establishment of refugee camps, Cote d'Ivoire does not. Rather than flee from Liberia to UNHCR camps, these Liberian refugees lived amongst Ivoirians in the capital, Abidjan, and elsewhere around the country. Prior to arriving in the United States the bulk of their bureaucratic encounters occurred not with the UNHCR but with U.S. government officials in West Africa.

iv I use the terms Black Americans and Black people throughout the paper rather than other terminology because these are the labels used by my informants. For the same reason, I also use the terms White people and White Americans.

${ }^{\mathrm{v}}$ None of the individuals I studied had a Liberian passport or the birth certificate to prove Liberian citizenship. The Liberian embassy in the U.S. allows for a Liberian refugee to request passports if three individuals with Liberian passports/citizenship living in Liberia can certify that $\mathrm{s} / \mathrm{he}$ is a citizen. The individual must also pay a fee of $\$ 200$. This 
process is arduous and impossible for many refugees to complete because their relatives and friends are scattered across West Africa and do not have citizenship papers themselves. Returning to Liberia permanently or temporarily is therefore a difficult task. ${ }^{\text {vi }}$ From 1822 to 1847 , White American slave owners ruled the country under the auspices of the quasi-colonial American Colonization Society (ACS). After this point, foreign Black settlers (primarily freed slaves from the U.S.) established authoritarian rule in the country. The decades of civil strife in Liberian in the $20^{\text {th }}$ century stem largely from the animosities between Black settlers and indigenous Liberians (Levitt 2005). However, refugees in this Oakland community regularly recall the historical link between the U.S. and Liberia. As one informant explained, referencing the refugee resettlement volunteers that assist him, "America is like Liberia's volunteer." Although this relationship to the U.S. is a part of Liberia's collective national identity (Wells 2008), beliefs about contemporary U.S. sympathies toward Liberia were speculation on the part of these refugees rather than a reflection of detailed knowledge about U.S. foreign policy. vii Interestingly, for the same reason the resettlement workers also tell them to check the "Other" box for race and write in "Liberian" instead of checking the box for "Black or African-American.”

viii In the 1990s, the immigration of foreign-born Blacks to the United States accounted for $25 \%$ of total Black population growth (Roberts 2005).

ix In this paper, I discuss race relations only in the context of racial distancing and boundary making and do not address whether these refugees faced racism or discrimination. During my research, my informants never expressed concerns about racism or discrimination. This may be because Black immigrants are more likely to 
interpret their inter-ethnic encounters as racism only after living in the U.S. for a longer period of time (Waters 1999). For the refugees in this study, racism and discrimination will likely become issues of increasing importance over time and into the second generation. Future research can elaborate more fully on these patterns and the interactions between racism and refugee status.

${ }^{x}$ When asked, these individuals would say that they are "Black" themselves, just "not Black like American Blacks.”

${ }^{x i}$ Only rarely did the individuals in this study reference other minority groups in the United States, but when they did they continued to classify groups on the basis of their perceived respect for relationships and care giving. Thus, they viewed "Spanish" people as poor people who, despite their poverty, are savvy about managing their money in ways that allow them to help others. They portray Muslims, similarly, as generous and willing to help those in need as evidenced by zakat, the pillar that mandates alms-giving. xii This reference to their future in the United States was always vague. During my fieldwork, the individuals expressed very few sentiments or expectations about the future. Their concerns were much more about their daily survival. 